\title{
Cloacal Exstrophy: a complex disease
}

\author{
Antonio Macedo Jr, Atila Rondon, Ricardo Frank, Herick Bacelar, Bruno Leslie, Sergio Ottoni, Gilmar Garrone, \\ Riberto Liguori, Valdemar Ortiz
}

Division of Urology, Universidade Federal de São Paulo, São Paulo, Brazil

\begin{abstract}
Introduction: Cloacal exstrophy is a rare occurrence with an incidence of 1:200,000 to 1:400,000 live births. It represents one of the most challenging reconstructive endeavors faced by pediatric surgeons and urologists. Aside from the genitourinary defects, there are other associated anomalies of the gastrointestinal, musculoskeletal and neurological systems that require a multidisciplinary approach when counseling anxious parents.

Material and Methods: We present a video of a patient with cloacal exstrophy treated with 21 days of life. Surgery consisted of separation and tubularization of the cecal plate from the exstrophied bladder halves and colostomy construction. The bladder was closed primarily and umbilical scar reconstructed and used for ureteral and cistostomy drainage. A urethral catheter was used to guide bladder neck tubularization. A final epispadic penis was obtained and planned for further repair in a second step.

Results: The patient had an initial uneventful postoperative course and immediate outcome was excellent. The bladder healed nicely but patient presented with abdominal distension in the 5th day of postoperative setting requiring parenteral nutrition. The distal colon persisted with lower diameter although non obstructive, but causing difficulty for fecal progression. Continuous colostomy dilatation and irrigation were required.

Conclusions: Approximating the bladder halves in the midline at birth and primary bladder closure is a viable option, intestinal transit may be a issue of concern in the early postoperative follow-up.
\end{abstract}

\section{ARTICLE INFO}

Available at: www.brazjurol.com.br/videos/november_december_2013/Rondon_897_898video.htm

Int Braz J Urol. 2012; 39 (Video \#16): 897-8

Submitted for publication:

September 10, 2013

Correspondence address:

Atila Rondon, MD

Rua Maestro Cardim, 560 / 215

Accepted after revision:

São Paulo, SP, 01323-000, Brazil

November 25, 2013

Fax+ 5511 3287-3954

E-mail: atilarondon@hotmail.com 


\section{EDITORIAL COMMENT}

The video by Macedo et al. nicely depicts the first-stage repair of a cloacal exstropy variant. Cloacal exstrophy is an uncommon, complex congenital malformation with a reported incidence between 1 in 200,000 and 1 in 400,000 live births (1).

The patient depicted in the video had a fairly well-formed phallus with central union of the corporal bodies. Both testicles also appeared to be in a scrotal position. Frequently in patients with cloacal exstrophy, the penis is small and sep- arated into two hemiphalluses. This combined with wide pubic diastasis can make phallic reconstruction challenging. Frequently intra-abdominal testicles are encountered. Historically male-to-female gender reassignment with gonadectomy had been performed for children with severe phallic insufficiency. Matthews and colleagues examined testicles removed during gender reassignment surgery and found that they appeared histologically normal (2). The development of gender identity begins early in gestation, is multifactorial and incompletely understood. Increased reports of gender identity issues have resulted in reconsideration of routine sex reassignment $(3,4)$.

\section{REFERENCES}

1. Woo LL, Thomas JC, Brock JW: Cloacal exstrophy: a comprehensive review of an uncommon problem. J Pediatr Urol. 2010; 6: 102-11.

2. Mathews RI, Perlman E, Marsh DW, Gearhart JP: Gonadal morphology in cloacal exstrophy: implications in gender assignment. BJU Int. 1999; 84: 99-100.
3. Reiner WG: Psychosexual development in genetic males assigned female: the cloacal exstrophy experience. Child Adolesc Psychiatr Clin N Am. 2004; 13: 657-74, ix.

4. Reiner WG, Gearhart JP: Discordant sexual identity in some genetic males with cloacal exstrophy assigned to female sex at birth. N Engl J Med. 2004; 350: 333-41.

Hubert Swana, MD Pediatric Urology Nemours Children's Hospital Orlando E-mail: hswana@nemours.org 